\title{
PCR assay for improved diagnostics of epitheliotropic disease virus (EEDV) in lake trout Salvelinus namaycush
}

\author{
T. Kurobe ${ }^{1}$, S. Marcquenski ${ }^{2}$, R. P. Hedrick ${ }^{1, *}$ \\ ${ }^{1}$ Department of Medicine and Epidemiology, School of Veterinary Medicine, University of California, Davis, \\ California 95616, USA \\ ${ }^{2}$ Wisconsin Department of Natural Resources, Box 7921 Madison, Wisconsin 53707, USA
}

\begin{abstract}
Epizootic epitheliotropic disease virus (EEDV) has caused catastrophic losses among hatchery-reared juvenile lake trout Salvelinus namaycush since the early 1980s and remains a major impediment to lake trout restoration in the Great Lakes basin of the USA. Although EEDV has been tentatively designated as a herpesvirus based upon morphological criteria, further characterization of the virus and development of improved detection methods have been hampered by the inability to propagate the virus in cell culture. Recently obtained sequence data for a region of the putative terminase gene from EEDV as well as the related Salmonid herpesvirus 1 and 2 have permitted the development of a polymerase chain reaction (PCR) assay for specific detection of EEDV. The new EEDV PCR demonstrated both an excellent analytic sensitivity and specificity and detected viral DNA as present in the skin of lake trout during periods of active viral outbreaks. In addition, EEDV DNA was detected among healthy appearing juveniles and in the ovarian fluids of spawning adults. Here we describe the development and initial validation steps of the EEDV PCR as a replacement for current diagnostic methods that require virus extraction from the skin, partial purification by isopycnic centrifugation, and visualization of negatively-stained virions by electron microscopy.
\end{abstract}

KEY WORDS: Fish herpesvirus · Salmonid herpesvirus · Lake trout · EEDV

\section{INTRODUCTION}

Since the mid-1980s, hatchery populations of juvenile and yearling lake trout Salvelinus namaycush in the Lake Superior and Lake Michigan basins have experienced periodic epidemics of an epidermal disease (Bradley et al. 1989, McAllister \& Herman 1989, McAllister 1993). Epidemics were characterized by the rapid onset of mortality, which followed a set of nonspecific clinical signs including spiral swimming, lethargy, and periods of hyper-excitability (Bradley et al. 1989). Hemorrhages in the eyes were observed, and fish displayed a gray-white mucoid blotching of the skin and fins (McAllister \& Herman 1989). Secondary fungal infections were common, and mortality approached $100 \%$ of the affected hatchery populations of juvenile lake trout. The principal microscopic changes were hyperplasia of the epidermis with affected cells demonstrating a swollen cytoplasm and enlarged nucleus (Bradley et al. 1989). Initial reports suggested that epitheliocystis, due to an infection with an intracellular Gram-negative bacteria, was the potential cause of these disease outbreaks in lake trout hatcheries (McAllister \& Herman 1987, Bradley et al. 1988). However, later investigations revealed herpesvirus particles in affected hyperplastic epidermal cells of the skin as the more likely agent associated with the disease (Bradley et al. 1989, McAllister \& Herman 1989). The absence of consistent internal signs in affected fish led pathologists to conclude that this was a disease principally of the integument and primarly the skin, and thus the condition was termed epizootic epitheliotropic disease (EED) or lake trout epidermal hyperplasia (Bradley et al. 1989, Mc Allister \& Herman 
1989). The virus associated with EED has alternately been designated as EED virus or EEDV, lake trout herpesvirus, and Salmonid herpesvirus 3 (SalHV3). Recent phylogenetic studies of the Alloherpesviridae (fish and amphibian herpesviruses) by Waltzek et al. (2009), demonstrate that EEDV shares $\geq 81 \%$ similarity for the deduced amino acid sequences of regions of the DNA polymerase and terminase genes with both Salmonid herpesvirus 1 (SalHV1) and Salmonid herpesvirus 2 (SalHV2). The newly obtained DNA sequence data not only support designation of EEDV as SalHV3 but provide the potential to develop improved DNA-based diagnostic methods for EEDV.

As part of a lake trout restoration program in the Great Lakes basin in the 1980s, brood stocks were developed from remnant wild source populations. Outbreaks of EED appeared among the first progeny reared in both federal and state hatcheries. Unfortunately, hatchery water use and fish movements between facilities made it difficult to establish the original source(s) of infection. Initial management approaches were severe at affected hatcheries, with depopulation and complete disinfection required. As a result, over 15 million fish at federal and state hatcheries in Wisconsin and Michigan died or were destroyed due to EEDV. In addition, there were severe restrictions on the movements of hatchery populations of lake trout within the Great Lakes basin (EEDV policy of the Great Lakes Fish Health Committee 1988). In Wisconsin, lake trout eggs in the 1980s were obtained from wild adult lake trout from the Apostle Islands as well as from hatcheries in Michigan. Lake trout were reared on well water at the Bayfield and Westfield hatcheries, and EEDV outbreaks occurred at both facilities (Bayfield in 1987 and 1988; Westfield in 1988). A search for alternate sources of lake trout led to the import of eggs from a federal hatchery in Wyoming between 1990 and 1999, a period in which no new outbreaks at Wisconsin hatcheries were detected. In 2000, egg collections from wild lake trout from the Great Lakes basin (Apostle Islands) resumed and continued through 2007. Bayfield hatchery continues to rear lake trout, and since 1997, the hatchery has used untreated surface water from Lake Superior.

Early experimental studies with EEDV demonstrated transmission of the disease to naïve fish from infected fish via the water with skin scrapings/homogenates or contaminated equipment (McAllister 1993). Mortality among exposed fish generally began 7 to $14 \mathrm{~d}$ later, which corresponded to the incubation period for natural outbreaks among yearlings that experienced a stressful event in hatcheries (tagging, fin clipping, handling). Occurrence of the disease in fish following stressful periods may be due to activation of the virus from a low grade persistent or latent infection as sug- gested for the channel catfish virus (Ictalurid herpesvirus 1, IcHV1) in channel catfish Ictalurus punctatus populations (Thompson et al. 2005). Prevalence of the lake trout herpesvirus in both hatchery and wild stocks of lake trout has not been reported due to the lack of an accurate and practical diagnostic test. Also unknown is the potential for the virus to be vertically transmitted from infected brood stocks to progeny as occurs with certain fish herpesviruses (Wise et al. 1988). During outbreaks in juvenile lake trout, nucleocapsids of EEDV can be observed within the nuclei, and fully enveloped virus particles may be evident in the cytoplasm of infected epidermal cells (Bradley et al. 1989). The virions of EEDV observed in skin concentrates or in thin sections of skin possess the same size and structure of herpesviruses found in a range of fish as well as those found in other vertebrates and even those more recently discovered in bivalve mollusks (Davison et al. 2005a,b). Unfortunately, numerous attempts at inoculation of infected fish tissues onto established cell lines and primary cell cultures from salmonid fish, including lake trout, have failed to isolate the virus (McAllister 1993). Currently, a presumptive diagnosis depends upon observation of characteristic clinical signs of the disease in known susceptible species (lake trout and selected lake trout hybrids). Confirmatory diagnoses rely upon observation of characteristic herpesvirus particles following extraction from the skin, partial purification in sucrose gradients by ultracentrifugation, and their visualization by transmission electron microscopy (TEM). This latter method is not only rigorous, but also unwieldy when numerous samples are involved. In this report, we exploit the first gene sequence reported for the putative terminase gene for EEDV from our previous research (Waltzek et al. 2009). This sequence data was used to develop a polymerase chain reaction (PCR) test that effectively detects EEDV DNA as present in tissues of lake trout with and without clinical signs of EED.

\section{MATERIALS AND METHODS}

Fish. Archived tissues from juvenile lake trout were provided by Dr. Paul Bowser (Cornell University, Ithaca, NY, USA) and one of the authors (S. Marcquenski) from the Bayfield hatchery in Wisconsin. Ovarian fluids from spawning lake trout from the Apostle Islands of Lake Superior, USA, were collected by S. Marcquenski. Either whole fish, the full length lateral body skin, or ovarian fluids were frozen at $-70^{\circ} \mathrm{C}$ until shipment to the Fish Health Laboratory at the University of California, Davis, CA, USA. Juvenile lake trout collected in $1988(n=2), 2003(n=1)$, and $2006(n=11)$ were experiencing clinical signs consistent with EED, 
and the presence of EEDV by electron microscopy was confirmed from fish in both 1988 and 2003. Juvenile lake trout from $2001(n=5)$ were collected during periods of mortality in the hatchery population, but no evidence for EEDV was observed by electron microscopy. Another fish group was collected in 2007 ( $\mathrm{n}=11$ ) from apparently healthy lake trout. Additional sampling included ovarian fluids ( $\mathrm{n}=16$ ) from 2 adult spawning populations of lake trout in 2003 and 2006. Skin samples were not available from spawning fish as they were not lethally sampled. Fish samples were not collected from 1990 through 1999 since there was no active mortality due to EEDV disease.

Virus purification and extraction of genomic DNA. Virus was extracted from the skin of previously frozen juvenile lake trout by the method described by Bradley et al. (1989). Virus was further purified by separation on a linear sucrose gradient according to Gilad et al. (2002). The viral band was recovered and then resuspended in TNE buffer, composed of $50 \mathrm{mM}$ Tris- $\mathrm{HCl}$, $150 \mathrm{mM} \mathrm{NaCl}$, and $1 \mathrm{mM}$ disodium ethylenediaminetetraacetic acid (EDTA), pH 7.5. Viral genomic DNA was extracted with a mixture of 25:24:1 phenolchloroform-isoamyl alcohol (PCI) according to the protocol described by Tsai et al. (2005). Briefly, $400 \mu \mathrm{l}$ of lysis solution $(10 \mathrm{mM}$ Tris- $\mathrm{HCl} \mathrm{pH}$ 8.0, 1 mM EDTA, $100 \mathrm{mM} \mathrm{NaCl}, 0.2 \%$ SDS, $0.1 \mathrm{mg} \mathrm{ml}^{-1}$ Proteinase K) were added to $100 \mu \mathrm{l}$ of the purified virus and incubated at $50^{\circ} \mathrm{C}$ for $1 \mathrm{~h}$. Then, $400 \mu \mathrm{l}$ of PCI were added to the solution and shaken at room temperature for $20 \mathrm{~min}$. The sample was centrifuged at $8000 \times g$ at room temperature for $10 \mathrm{~min}$, and then the aqueous phase was transferred to a new tube. The viral genomic DNA was precipitated by adding 1/10 volume of $3 \mathrm{M}$ sodium acetate ( $\mathrm{pH} 5.2$ ) and 2.5 volumes of cold $99 \%$ ethanol. Precipitated DNA was rinsed with cold $75 \%$ ethanol, dried for $10 \mathrm{~min}$, and then dissolved in
$20 \mu \mathrm{l}$ of Tris- $\mathrm{HCl}$ ( $\mathrm{pH}$ 8.0) with EDTA buffer. A total of $5 \mathrm{ng}$ of extracted DNA was used as a template for subsequent PCR. The genomic DNA from other fish herpesviruses (Table 1) were extracted as described above.

Development and evaluation of the diagnostic PCR for EEDV. Primers specific for EEDV were designed based upon an alignment of the putative terminase genes for EEDV (EU349284), SalHV1 (EU349281), and SalHV2 Oncorhynchus masou virus: OMV (EU349282) (Fig. 1) as reported by Waltzek et al. (2009). Of the 2 forward and 3 reverse primers initially designed, only 1 primer set that showed the best analytical sensitivity and specificity was chosen for the EEDV diagnostic PCR (Table 2). Initial testing of the detection limits of each of the possible combinations of the forward and reverse primers was assessed at various PCR reaction conditions with plasmid DNA harboring the target fragment as template (Waltzek et al. 2009). Varying concentrations of the PCR reagents included: primer concentrations of 20 or 40 pmol; $\mathrm{MgCl}_{2}$ at either 0.5 , 1.5, or $2.5 \mathrm{mM}$; Platinum Taq polymerase (Invitrogen)

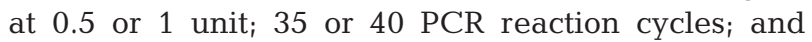
annealing temperatures of 50,55 , or $60^{\circ} \mathrm{C}$. Following the PCR, $10 \mu$ l of the PCR product were examined by electrophoresis for $20 \mathrm{~min}$ on a $2 \%$ agarose gel. The PCR product of $322 \mathrm{bp}$ from EEDV diagnostic PCR was revealed on a UV transilluminator following staining of the gel with a $0.1 \%$ ethidium bromide solution.

The detection limit of the optimized EEDV diagnostic PCR assay was examined using 10 -fold serial dilutions containing $1 \times 10^{6}$ to $1 \times 10^{-1}$ copies of the EEDV plasmid as template DNA. To test the influence of lake trout genomic DNA on the PCR, $200 \mathrm{ng}$ of fish genomic DNA extracted from control lake trout were added to the cocktail for each PCR. The analytic specificity or the ability of the PCR to amplify EEDV DNA but not

Table 1. Isolates, host species, and location originally identified for viruses used in the present study. Accession numbers are provided in the 'Materials and methods' for those viruses for which sequence data were used to develop the epitheliotropic disease virus (EEDV)-specific and salmonid herpesvirus generic PCR primers

\begin{tabular}{|llcl|}
\hline Virus and isolate & Host species & Location & Source \\
\hline EEDV & Salvelinus namaycush & USA & Bradley et al. (1989), \\
& & & $\begin{array}{c}\text { McAllister \& Herman (1989) } \\
\text { Salmonid herpesvirus 1 (SalHV1) }\end{array}$ \\
Salmonid herpesvirus 2 (SalHV2) & Oncorhynchus mykiss & USA & Wolf \& Taylor (1975) \\
Ictalurid herpesvirus 1 (IcHV1) & Ictalurus punctatus & Japan & Kimura et al. (1980) \\
Ictalurid herpesvirus 2 (IcHV2) & Ameiurus melas & USA & Fijan et al. (1970) \\
Cyprinid herpesvirus 1 (CyHV1) & Cyprinus carpio & Italy & Alborali et al. (1996) \\
Cyprinid herpesvirus 2 (CyHV2) & Carassius auratus & Japan & Sano et al. (1985) \\
Cyprinid herpesvirus 3 (CyHV3) & Cyprinus carpio & Japan & Jung \& Miyazaki (1995) \\
Acipenserid herepsvirus 1 (AciHV1) & Acipenser transmontanus & USA & Hedrick et al. (2000) \\
Acipenserid herpesvirus 2 (AciHV2) & Acipenser transmontanus & USA & Hedrick et al. (1991) \\
White seabass herpesvirus (WSBHV) & Atractoscion nobilis & Watson et al. (1995) \\
& & USA & Authors' unpubl. data \\
\hline
\end{tabular}




\begin{tabular}{|c|c|c|}
\hline & >>>>>>>>>>>>>>>>>>>> $236 \mathrm{~F}$ & \\
\hline EEDV & СТСАССТССАTСAСTAGTCTGATCCCССTCATGCTGGTCGCCGGGCGAAAGCAGATCCAC & 95 \\
\hline SalHV1 & 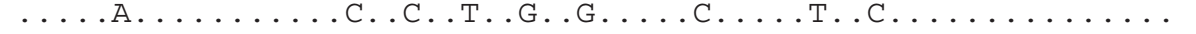 & 94 \\
\hline \multirow[t]{2}{*}{ SalHV2 } & $\ldots$....G.T. . . . . . . . TT.G.... . . . . . . . . . . . . . & 420 \\
\hline & >>>>>>>>>>>>>>> & \\
\hline EEDV & АTTTCTTCCCACGTGGCCAAATCTTGGATTAACAACGTGGGCGACATTATCGACGAAACA & 155 \\
\hline SalHV1 & . С....G.T........G....G. & 154 \\
\hline \multirow[t]{2}{*}{ SalHV2 } & 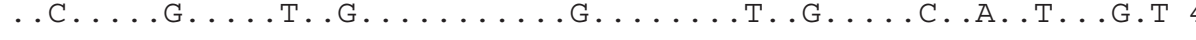 & 480 \\
\hline & $\gg 223 \mathrm{~F}$ & \\
\hline EEDV & ACGGGGGAGCCGGCGTTTCATGTTATCTCTCAGAAGTTTAAATGCGGTGCGCACATGCAC & 215 \\
\hline SalHV1 & .С.А...Т..........С. & 214 \\
\hline \multirow[t]{2}{*}{ SalHV2 } & .Т...Т.Т.... & 540 \\
\hline & $<<<<<<<<<<$ & \\
\hline EEDV & СTACCAGGTCTGACGTGTCCCTGTGAAGCAGTCTACTGCCCCAGTCACATAGATATGAAC & 275 \\
\hline SalHV1 & 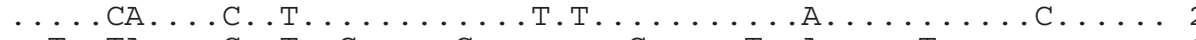 & 274 \\
\hline \multirow[t]{2}{*}{ SalHV2 } & 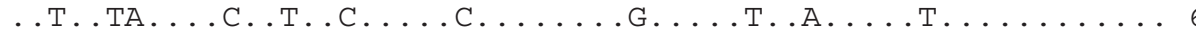 & 600 \\
\hline & $<340 \mathrm{R}$ & \\
\hline EEDV & CCCGCTACGCAGGCCCTGCTCAGCTGTGTGGCCCCCGGGGGAGAAATGGAGATCACAGGT & 335 \\
\hline SalHV1 & .Т.А.АА...Т...Т. .Т. & 334 \\
\hline \multirow[t]{2}{*}{ SalHV2 } & ...С.А.А.Т.Т.......А.Т..С & 660 \\
\hline & $<<<<<<<<~$ & \\
\hline EEDV & GGCACCGGTGACTTGGGTAATCTGGTGTCGGACTCGACCTTCCCCTTCCCAGATGAGACG & 395 \\
\hline SalHV1 & 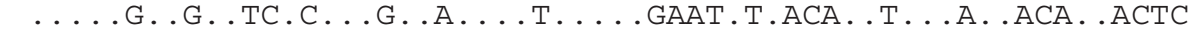 & 394 \\
\hline \multirow[t]{2}{*}{ SalHV2 } & 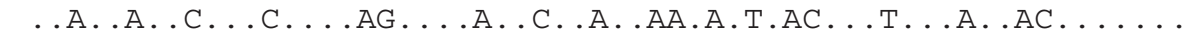 & 720 \\
\hline & $<<<<<<<<<230 R$ & \\
\hline EEDV & GTGCACAAGATAATGAACGATGTGATTGATA & 455 \\
\hline SalHV1 & 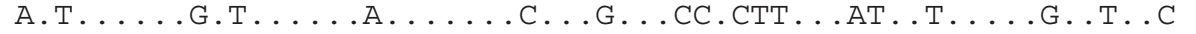 & 454 \\
\hline \multirow[t]{3}{*}{ SalHV2 } & . CA..T. .TAAGA.G..G..G..A..A & 780 \\
\hline & $\ll<<231 R$ & \\
\hline & $\ll<<<<224 R$ & \\
\hline EEDV & TTСТАСАTTGCСАTTGACСCСАССТАTTСTTCCGGCAGCCAATCGTCAATG 506 & \\
\hline SalHV1 & 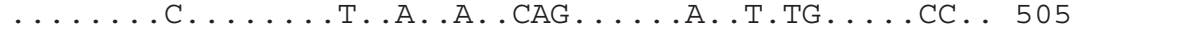 & \\
\hline SalHV2 & 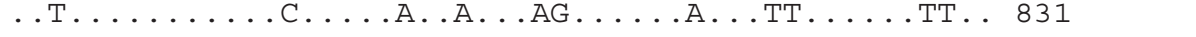 & \\
\hline
\end{tabular}

Fig. 1. Primers designed for development of diagnostic PCR assay for epitheliotropic disease virus (EEDV). A DNA alignment was generated using Clustal W software based on the terminase genes from 3 salmonid herpesviruses, EEDV (EU349284), SalHV1 (EU349281), and SalHV2:OMV (EU349282), obtained in a previous study (Waltzek et al. 2009). Nucleotides identical to EEDV shown by dots. Primer sequences indicated in bold and with arrows. Numbers represent the position of the sequence

that from 10 other fish herpesviruses was also examined. The fish herpesviruses tested included: the closely related salmonid herpesviruses SalHV1 and SalHV2, Acipenserid herpesvirus 1 (AciHV1), AciHV2, Cyprinid herpesvirus 1 (CyHV1), CyHV2, CyHV3, Ictalurid herpesvirus 1 (IcHV1), IcHV2, and the White seabass herpesvirus WSBHV (Table 1). The genomic DNA of WSBHV was extracted from partially purified virus from infected fish, while all other DNA was extracted from the media of virus-infected cell cultures. Each reaction contained approximately $10 \mathrm{ng}$ of the DNA as template, and the PCR was performed as described above. Approximately $10 \mathrm{ng}$ of fish genomic DNA from a skin sample from a fish infected with EEDV, as confirmed by electron microscopy (Bradley et al. 1989), were used as a positive control for this reaction. Water was added for the negative control.
A second PCR test with generic primers was designed to detect salmonid herpesviruses potentially present but not amplified with the EEDV diagnostic PCR. These generic primers were applied to all diagnostic samples examined with the EEDV PCR. The generic salmonid herpesvirus PCR test utilized a primer set (339F 5'-AAG CAG ATC CAC ATT TCT TC -3' and 340R 5'-GGG TTC ATA TCT ATG TGA C-3') that was designed for a conserved region of the terminase gene for SalHV1, SalHV2, and EEDV (Fig. 1). The reaction was performed as follows: initial denaturation step of $95^{\circ} \mathrm{C}$ for $5 \mathrm{~min} ; 40$ cycles of $95^{\circ} \mathrm{C}$ for $30 \mathrm{~s}, 60^{\circ} \mathrm{C}$ for $30 \mathrm{~s}$, and $72^{\circ} \mathrm{C}$ for $30 \mathrm{~s}$; followed by a final extension step at $72^{\circ} \mathrm{C}$ for $5 \mathrm{~min}$; and then held at $4^{\circ} \mathrm{C}$. The PCR product (194 bp) was separated on $2 \%$ agarose gels and observed by a transilluminator after staining with a $1 \%$ ethidium bromide solution for $20 \mathrm{~min}$. 
Table 2. Primers based upon the putative terminase gene of epitheliotropic disease virus (EEDV) for the development of a diagnostic PCR assay and the amplicon size for each primer combination (bp)

\begin{tabular}{|llccc}
\hline \multirow{2}{*}{ Primer } & \multirow{2}{*}{ Sequence (5' to 3') } & \multicolumn{3}{c}{ Amplicon size (bp) with } \\
& & $224 \mathrm{R}$ & 230R & 231R \\
\hline 223F & CAT TAT CGA CGA AAC AAC G & $322^{\mathrm{a}}$ & 267 & 320 \\
236F & TCA CCT CCA TCA CTA GTC TG & 425 & 370 & 423 \\
224R & GTA GAA AGC CGA AAC TTC G & & & \\
230R & ATC TTG TGC ACC GTC TCA TC & & & \\
231R & AGA AAG CCG AAA CTT CGG CG & & & \\
& &
\end{tabular}

${ }^{a}$ The analytical sensitivity of this primer set is 10 -fold higher than the others

\section{RESULTS}

\section{Development of a diagnostic PCR assay}

Various combinations of forward and reverse primers were tested to obtain the optimal detection limit of the assay for EEDV DNA. The primer set $223 \mathrm{~F}$ and 224R showed 10-fold higher sensitivity than other primer sets (Table 2) (data not shown). The analytic sensitivity of the diagnostic PCR assay was as few as 10 copies of target DNA in the presence of fish genomic DNA (Fig. 2). There was no significant difference in the sensitivity of the assay when either 0.5 or $1 \mathrm{U}$ of Taq polymerase was used. Optimal parameters for PCR amplification were determined to be:

Cocktail: $1.5 \mathrm{mM} \mathrm{MgCl} 2,1 \times$ buffer, $200 \mu \mathrm{M}$ dNTPs, 40 pmol primers, $0.5 \mathrm{U}$ Platinum Taq polymerase (Invitrogen)

Template: $200 \mathrm{ng}$ of fish genomic DNA

Cycling conditions: $95^{\circ} \mathrm{C}$ for $5 \mathrm{~min}, 95^{\circ} \mathrm{C}$ for $30 \mathrm{~s}$, $60^{\circ} \mathrm{C}$ for $30 \mathrm{~s}, 72^{\circ} \mathrm{C}$ for $30 \mathrm{~s}, 40$ cycles, $72^{\circ} \mathrm{C}$ for $5 \mathrm{~min}$

Forward primer: 223F 5'-CAT TAT CGA CGA AAC AAC G-3'

Reverse primer: 224R 5'-GTA GAA AGC CGA AAC TTC G-3'

Size of amplicon: $322 \mathrm{bp}$

Tests of the analytic specificity of the EEDV PCR showed no evidence for the amplification of DNA from

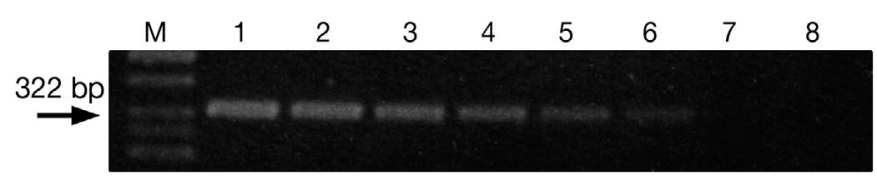

Fig. 2. Analytical sensitivity or limits of detection of epitheliotropic disease virus DNA by the diagnostic PCR assay for EEDV. Ethidium bromide-stained agarose gel demonstrating the analytical sensitivity of the diagnostic PCR assay for EEDV. The detection limit was tested using 10-fold serial dilutions from $1 \times 10^{6}$ to $1 \times 10^{-1}$ copies of the plasmid carrying the target DNA fragment as mixed with $200 \mathrm{ng}$ of lake trout DNA (Lanes 1 to 8). Arrow: expected amplicon size (322 bp), M: molecular weight marker any of the other 10 fish herpesviruses examined (Fig. 3).

\section{Examination of lake trout for the presence of EEDV DNA}

Viral DNA was detected in 20 of the 46 fish examined as present either in the skin or ovarian fluid samples (Table 3). While fish samples collected in 2001 were negative by the assay, EEDV DNA was detected from the other groups collected in 1988, 2003, 2006, and 2007. The virus DNA was detected not only from skin but also ovarian fluid. Three PCR amplicons from 3 different years were chosen randomly and sequenced, and they all showed sequences identical to the original EEDV terminase gene sequence used for development of the PCR assay. An examination of all of the same samples from lake trout using the generic salmonid herpesvirus PCR provided similar results but with fewer positive fish. All 15 fish found positive by the generic PCR were also positive by the EEDV PCR. The plasmid DNA carrying the target sequence was used as a positive control for this reaction. DNA elution buffer supplied in the DNA extraction kit served as the negative control (QIAamp Mini Kit, Qiagen).

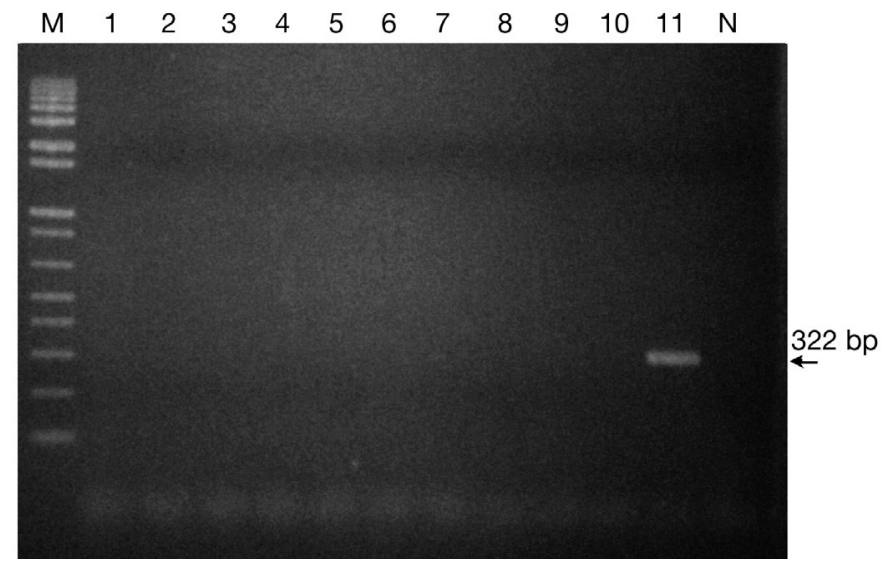

Fig. 3. Analytical specificity or the ability of the epitheliotropic disease virus diagnostic PCR assay to discriminate EEDV from other fish herpesviruses. Ethidium bromidestained agarose gel demonstrating the analytic specificity of the diagnostic PCR assay for EEDV. The expected PCR amplicon is indicated by the arrow. Lane 1: Salmonid herpesvirus 1 (SalHV1), Lane 2: SalHV2, Lane 3: Acipenserid herpesvirus 1 (AciHV1), Lane 4: AciHV2, Lane 5: Cyprinid herpesvirus 1 (CyHV1), Lane 6: CyHV2, Lane 7: CyHV3, Lane 8: Ictalurid herpesvirus (IcHV1), Lane 9: IcHV2, Lane 10: White seabass herpesvirus, Lane 11: EEDV. Approximately $10 \mathrm{ng}$ of DNA was used for each reaction. N: water control 
Table 3. Detection of epitheliotropic disease virus (EEDV) DNA by the EEDV PCR assay in samples collected from juvenile (skin) and adult spawning (ovarian fluid) lake trout in different years and at 2 locations in the Lake Superior basin. n/a: not attempted

\begin{tabular}{|c|c|c|c|c|c|c|}
\hline Year & Location & Tissue type & EM test & Mortality & PCR positive & $\begin{array}{c}\text { Number of } \\
\text { fish examined }\end{array}$ \\
\hline 1988 & Bayfield, WI & Skin & + & + & 2 & 2 \\
\hline $2001^{\mathrm{a}}$ & Bayfield, WI & Skin & $\mathrm{n} / \mathrm{a}$ & + & 0 & 5 \\
\hline \multirow[t]{2}{*}{2003} & Bayfield, WI & Skin & + & + & 1 & 1 \\
\hline & Apostle Islands, Lake Superior & Ovarian fluid & + & - & 3 & 10 \\
\hline \multirow[t]{2}{*}{2006} & Bayfield, WI & Skin & - & + & 10 & 11 \\
\hline & Apostle Islands, Lake Superior & Ovarian fluid & - & - & 2 & 6 \\
\hline 2007 & Bayfield, WI & Skin & $\mathrm{n} / \mathrm{a}$ & - & 2 & 11 \\
\hline
\end{tabular}

\section{DISCUSSION}

The new putative sequences for the DNA polymerase and terminase genes of EEDV confirm that the virus is most closely related to 2 other known salmonid herpesviruses, SalHV1 and SalHV2, and to a lesser extent a larger group of fish and amphibian viruses (Waltzek et al. 2009). The EEDV genomic sequence data was used to develop a diagnostic PCR test that was able to detect EEDV DNA in the skin of juvenile lake trout undergoing active EED outbreaks in 1988, 2003, and 2006 as well as among fish not undergoing an EED outbreak in 2007. In contrast, EEDV DNA was not detected in lake trout that died from Aeromonas salmonicida and Ichthyophthirius infections in 2001. Lastly, viral DNA was detected in the ovarian fluids from spawning adult lake trout, which may indicate the potential for vertical or egg-associated transmission of this important pathogen of lake trout.

Several herpesviruses have been described among salmonid fishes (Wolf 1988). The majority are found in Japan infecting Pacific salmon, with the remaining viruses from rainbow trout or steelhead Oncorhynchus mykiss from the western USA (Hetrick \& Hedrick 1993) or lake trout or splake (a hybrid between lake trout and brook trout Salvelinus fontinalis) from the Great Lakes Basin of the USA (Bradley et al. 1989, McAllister \& Herman 1989). Serologic and DNA hybridization studies suggest that salmonid herpesviruses described in Japan form a single group (SalHV2), while the isolates from the western USA form a related but separate group, SalHV1 (Hedrick et al. 1987, Eaton et al. 1991). The recent study by Waltzek et al. (2009) confirms the relatedness of SalHV1 and SalHV2, which appear to represent viruses that evolved with salmonids from the Pacific region (Davison 1998). In contrast, EEDV is clearly less related to SalHV1 and SalHV2 than the latter are to each other (Waltzek et al. 2009), suggesting that EEDV is a virus more adapted to the chars (genus Salvelinus) and perhaps specifically to lake trout. Lake trout are native to the northern latitudes of North America, with their historic range determined primarily by the extent and dynamics of the Pleistocene glaciations (Wilson \& Hebert 1998). The native range for lake trout includes portions of all of the Canadian provinces (except Newfoundland and Prince Edward Island), as well as Alaska, Illinois, Indiana, Maine, Massachusetts, Michigan, Minnesota, Montana, New Hampshire, New York, Ohio, Pennsylvania, Vermont, and Wisconsin in the USA (NatureServe 2004). Determining how broadly EEDV might be distributed among these separate populations of lake trout is now possible with the more sensitive diagnostic methods described in this report. That EEDV is highly adapted to the lake trout host and not Pacific or other salmonids is implied from field observations and experimental trials (McAllister \& Herman 1989). During active outbreaks in lake trout, Chinook salmon $O$. tshawytscha and brook trout were not affected, and subsequent experimental trials extended the number of salmonid hosts refractory to disease to include rainbow trout, Atlantic salmon Salmo salar, and brown trout $S$. trutta (McAllister \& Herman 1989). Prior studies were unable to determine whether refractory salmonid hosts for EEDV could potentially become infected transiently or for more protracted periods in part due to the absence of a practical and sensitive diagnostic test. Such studies are now possible with the newly developed PCR for EEDV.

The PCR test developed in the present study was effective in detecting as few as 10 copies of target DNA and thus provided a very sensitive and specific indicator of the presence of viral DNA in tissue samples (Figs. 2 \& 3). An application of the optimized PCR test to tissue samples of juvenile or adult lake trout at 2 Wisconsin locations demonstrated that viral DNA was readily detected during EED outbreaks as well as among juveniles and adults with no clinical signs of disease (Table 3). Additionally, viral DNA was detected across different years when the source of 
lake trout eggs or the water supply for the Bayfield hatchery was Lake Superior (i.e. 1988, and several times from 2000 to 2007). This indicates the persistence of the virus at a minimum in the one lake trout hatchery and a wild spawning population. Testing of archival samples that may predate the 1988 epidemics is planned with the idea that EEDV may have indeed been present, as suggested by local observers, in lake trout populations for the past 30 to $40 \mathrm{yr}$.

To address the concern that lake trout herpesviruses present at endemic hatcheries might not be detected by the new PCR, all diagnostic samples and appropriate EEDV, SalHV1 and SalHV2 controls were also subjected to a second PCR test designed with generic primers to amplify salmonid fish herpesvirus DNA. This second test did not identify any additional samples as positive beyond those tested with the specific EEDV PCR. This result suggests that it is unlikely that salmonid herpesviruses other than EEDV, as detected by the new PCR test, were present in the tissues tested.

Among the skin and ovarian fluids examined by the PCR assay, 20 of 46 samples demonstrated evidence for EEDV infection (Table 3). Although sample sizes were limited, fish examined in 2001 showed no evidence for EEDV infection, which contrasts the positive results from 1988, 2003, 2006, and 2007. Skin from the body and fins are suggested targets for viral infection based upon histopathological and electron microscopical studies of infected lake trout (Bradley et al. 1989, McAllister \& Herman 1989). The presence of viral DNA and likely virus in ovarian fluids is a new observation. The presence of virus in spawning females is a common finding for both SalHV1 and SalHV2, which are routinely recovered in ovarian fluids (Wolf 1988). Although difficult to prove, vertical transmission of the salmonid herpesviruses likely occurs at some frequency, perhaps very low. Vertical transmission had been clearly demonstrated for at least one fish herpesvirus, IcHV1 (Wise et al. 1988, Thompson et al. 2005). The presence of EEDV DNA and likely EEDV in both the cellular and fluid fractions of lake trout ovarian fluid (which is in intimate contact with the eggs) provides evidence for potential vertical transmission, a mode suspected in certain EED outbreaks in hatcheries that use well water (S. Marcquenski unpubl. obs.). The ability to detect EEDV DNA in ovarian fluid provides an additional tool for aiding in the prevention of viral outbreaks in hatcheries as selective screening and mating of adult lake trout raised in isolated conditions might break vertical transmission cycles. That other tissues from lake trout adults, including male reproductive fluids, could harbor virus will be examined in the next spawning cycle.

EEDV, and likely all 3 salmonid herpesviruses, have epitheliotropic characteristics, a feature shared by most fish and many animal herpesviruses (Davison 2002). That EEDV can reside in the skin of juvenile lake trout with no clinical signs of disease is suggested by the detection of viral DNA in samples from 2007 (Table 3). This may indicate that EEDV is likely present even in years when no disease episodes are observed. The presence of virus carriers is consistent with the observations that many EEDV episodes occur when apparently healthy populations are subjected to stressors common to hatchery operations (e.g. crowding, movements, tagging), a feature in common with stress-induced IcHV1 outbreaks in channel catfish (Thompson et al. 2005).

Twenty years have passed since the initial observations of the virus associated with EED by Bradley et al. (1989) and McAllister \& Herman (1989). Confirmed and suspected outbreaks due to the virus have continued among juvenile lake trout in several Great Lakes basin hatcheries in the intervening years. The development of the EEDV PCR test provides a new and critically needed approach to detection of the virus that allows a more practical, timely, and precise means of confirming outbreaks. Additionally, and perhaps more importantly in the long term, the new diagnostic testing has begun and will continue to uncover features of the virus-host relationship critical to the control of this serious disease of lake trout.

Acknowledgements. We thank T. S. McDowell for technical assistance. We also appreciate the assistance of Professor P. Bowser, who provided frozen fish tissues, Dr. H. Fukuda for virus isolates, and Dr. Phil McAllister for his advice. This research was supported in part by Grant no. 00132-022008 from the Great Lakes Fisheries Commission, by the California Department of Fish and Game, and Federal Aid in Sport Fish Restoration Project F-95-P.

\section{LITERATURE CITED}

Alborali L, Bovo G, Lavazza A, Cappellaro H, Guadagnini PF (1996) Isolation of an herpesvirus in breeding catfish (Ictalurus melas). Bull Eur Assoc Fish Pathol 16:134-137

Bradley TM, Newcomer CE, Maxwell KO (1988) Epitheliocystis associated with massive mortalities of cultured lake trout Salvelinus namaycush. Dis Aquat Org 4:9-17

> Bradley TM, Medina DJ, Chang PW, McClain J (1989) Epizootic epitheliotropic disease of lake trout (Salvelinus namaycush): history and viral etiology. Dis Aquat Org 7:195-201

> Davison AJ (1998) The genome of salmonid herpesvirus 1. J Virol 72:1974-1982

Davison AJ (2002) Evolution of the herpesviruses. Vet Microbiol 86:69-88

Davison AJ, Eberle R, Hayward GS, McGeoch DJ and others (2005a). Family Herpesviridae. In: Fauquet CM, Mayo MA, Maniloff J, Desselberger U, Ball LA (eds) Virus taxonomy: classification and nomenclature of viruses. 8th Rep Int Comm Taxon Viruses. Elsevier Academic Press, Amsterdam, p 203-225 
Davison AJ, Trus BL, Chen N, Steven AC and others (2005b) A novel class of herpesvirus with bivalve hosts. J Gen Virol 86:41-53

Eaton WD, Wingfield WH, Hedrick RP (1991) Comparison of the DNA homologies of five salmonid herpesviruses. Fish Pathol 26:183-187

Fijan NN, Wellborne TL, Naftel JP (1970) An acute viral disease of channel catfish. US Sport Fish Wildl Tech Pap No. 43

Gilad O, Yun S, Andree K, Adkison M and others (2002) Initial characterization of koi herpesvirus and development of a polymerase chain reaction (PCR) assay to detect the virus in koi Cyprinus carpio. Dis Aquat Org 48:101-108

Hedrick RP, McDowell T, Eaton WD, Kimura T, Sano T (1987) Serological relationships of five herpesviruses isolated from salmonid fishes. J Appl Ichthyology 3:87-92

Hedrick RP, McDowell TS, Groff JM, Yun SC, Wingfield WH (1991) Isolation of an epitheliotrophic herpesvirus from white sturgeon Acipenser transmontanus. Dis Aquat Org 11:49-55

Hedrick RP, Gilad O, Yun S, Spangenberg JV and others (2000) A herpesvirus associated with mass mortality of juvenile and adult koi, a strain of a common carp. J Aquat Anim Health 12:44-57

Hetrick FM, Hedrick RP (1993) New viruses described in finfish from 1988-1992. Annu Rev Fish Dis 3:187-207

Jung SJ, Miyazaki T (1995) Herpesviral haematopoietic necrosis of goldfish, Carassius auratus (L). J Fish Dis 18:211-220

Kimura T, Yoshimizu M, Tanaka M (1980) Salmonid viruses: a syncytium-forming herpesvirus from landlocked Oncorhynchus masou. Am Fish Soc Fish Health Sec Newsl 9:3

McAllister PE (1993) Salmonid fish viruses. In: Stoskopf MK (ed) Fish medicine. WB Saunders, Philadelphia, PA, p 383-384

McAllister PE, Herman RL (1987) Chlamydia-like organism associated with high mortality in hatchery reared lake

Editorial responsibility: Mark Crane,

Geelong, Victoria, Australia trout Salvelinus namaycush. Am Fish Soc Fish Health Sec Newsl 15:6

McAllister PE, Herman RL (1989) Epizootic mortality in hatchery-reared lake trout Salvelinus namaycush caused by a putative virus possibly of the herpesvirus group. Dis Aquat Org 6:113-119

NatureServe (2004) NatureServe Explorer: an online encyclopedia of life [web application]. Version 4.0. NatureServe, Arlington, VA. Available at: www.natureserve.org/ explorer

Sano T, Fukuda H, Furukawa M, Hosoya H, Moriya Y (1985) A herpesvirus isolated from carp papilloma in Japan. Fish Shellfish Pathol 32:307-311

- Thompson DJ, Khoo LH, Wise DJ, Hanson LA (2005) Evaluation of channel catfish virus latency on fingerling production farms in Mississippi. J Aquat Anim Health 17:211-215

Tsai CT, Ting JW, Wu MH, Wu MF, Guo IC, Chang CY (2005) Complete genome sequence of the grouper iridovirus and comparison of genomic organization with those of other iridoviruses. J Virol 79:2010-2023

Waltzek TB, Kelley GO, Alfaro ME, Kurobe T, Davison AJ, Hedrick RP (2009) Phylogenetic relationships in the family Alloherpesviridae. Dis Aquat Org (in press)

Watson LR, Yun SC, Groff JM, Hedrick RP (1995) Characteristics and pathogenicity of a novel herpesvirus isolated from adult and subadult white sturgeon Acipenser transmontanus. Dis Aquat Org 22:199-210

Wilson CC, Hebert PDN (1998) Phylogeography and postglacial dispersal of lake trout (Salvelinus namaycush) in North America. Can J Fish Aquat Sci 55:1010-1024

Wise JA, Harrell SF, Busch RL, Boyle JA (1988) Vertical transmission of channel catfish virus. Am J Vet Res 49: 1506-1509

Wolf K (1988) Fish viruses and fish viral diseases. Cornell University Press, Ithaca, NY

Wolf K, Taylor WG (1975) Salmonid herpesviruses: a syncytium-forming agent from rainbow trout. Am Fish Soc Fish Health Sec Newsl 4:3

Submitted: July 31, 2008; Accepted: December 11, 2008

Proofs received from author(s): February 27, 2009 